\title{
SORL1 Gene
}

National Cancer Institute

\section{Source}

National Cancer Institute. SORL1 Gene. NCI Thesaurus. Code C126509.

This gene is involved in both endocytosis and protein sorting. 